IN CONFIDENCE 
This page intentionally left blank 


\section{Ronald Goldfarb}

\section{IN CONFIDENCE}

WHEN TO PROTECT SECRECY AND WHEN TO REQUIRE DISCLOSURE

Yale University Press New Haven \& London 
Published with assistance from the Louis Stern Memorial Fund.

Copyright (C) 2009 by Ronald Goldfarb.

All rights reserved.

This book may not be reproduced, in whole or in part, including illustrations, in any form (beyond that copying permitted by Sections I07 and IO8 of the U.S. Copyright Law and except by reviewers for the public press), without written permission from the publishers.

Set in Galliard type by The Composing Room of Michigan, Inc. Printed in the United States of America by Sheridan Books, Ann Arbor, Michigan.

Library of Congress Cataloging-in-Publication Data

Goldfarb, Ronald L.

In confidence : when to protect secrecy and when to require disclosure / Ronald Goldfarb.

p. cm.

Includes bibliographical references and index.

ISBN 978-0-300-I2009-7 (cloth : alk. paper) I. Confidential communications-United States. 2. Privileges and immunities -United States. I. Title.

KF8958.G65 2009

$342.7308^{\prime} 58-\mathrm{dc} 22$

2008038670

A catalogue record for this book is available from the British Library.

This paper meets the requirements of ANSI/NISO Z39.48-I992 (Permanence of Paper). It contains 30 percent postconsumer waste (PCW) and is certified by the Forest Stewardship Council (FSC).

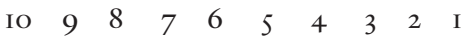


FOR ANABEL, CAITLIN, JOANNA, AVA, MILES, NATHANIEL, AND OTHERS WHO MAY JOIN THEM 
This page intentionally left blank 